\title{
Development Diplomacy as a Part of Public Diplomacy in the Pursuit of Foreign Policy Aims: Case of European Union Aid to Africa
}

\author{
Arakaza Dionise, PhD Candidate \\ Political Science, International Relations and Diplomacy, \\ Doctoral School of the University of Burundi
}

Doi:10.19044/esj.2020.v16n8p124～URL:http://dx.doi.org/10.19044/esj.2020.v16n8p124

\begin{abstract}
This paper examines how the European Union and other Western countries use the development aid to pursue their own interests. The paper presents an argument of how development aid is used to protect the citizens of donor countries and their properties in foreign countries. The argument details how the EU and the developed countries use development aid to promote their values and political ideologies linked with public diplomacy. The analysis focuses on the conditions given to beneficiary countries before receiving foreign aid. It also examines the behaviour of recipient nations in regard to supporting their donors. The researcher used the qualitative methodology by means of explanatory research to narrow the broad assumptions related to the research topic. The usefulness of the exploratory research approach relies on its appropriateness in analysing vast quantities of qualitative data by organising the data into specific themes that are recurrent in the data (Bearman, 2013). Exploratory research also helped the author to be creative in order to gain the most amount of insight on a subject as focused on theory building (Opoku, 2016). Secondary data from books, peer reviewed journals, and relevant government and OECD reports were applied to come out with the the findings. Data collected was analysed by applying a thematic approach due to the potential subjective nature of the qualitative data. Conclusion and recommendations were also given.
\end{abstract}

Keywords: Development Diplomacy, Foreign policy, European Union, Africa

\section{Introduction}

Providing aid to emerging countries is a common practice among developed nations. Given that developed nations are well endowed with resources and know-how, it is fair and moral that they give support to their 
fewer unfortunate counterparts. Also, consider that the United Nations, in a bid to achieve the 17 sustainable development goals, specifically emphasises the need for all countries of the world to assist each other in the realisation of the targets. Foreign aid can be financial, material, or in the form of expertise (Anup, 2014). It is given to help emerging countries realise progress in various areas, such as health, employment, innovation, governance, and many others (Zielińska, 2016). The European Union members and other Western nations have been giving aid to poor countries for many decades. However, one may ask, do superior states continue to provide and increase foreign aid to developing countries only for the sake of seeing their progress without the former pursuing their own interest? Consider that foreign assistance is costly to the donor. It involves transferring resources to other countries for free. Moreover, donor countries continue to provide aid to Africa, even when it is not a mandatory obligation. Again, it is not that donor countries have no use for the funds. Already, there are several projects waiting to be financed. These developed nations can as well concentrate on providing for the needy within their territories (Crawford et al., 2019). However, donors still choose to offer and continue increasing foreign aid to beneficiary countries. Is foreign aid really free? What do donors get in return for transferring resources to Africa and other developing countries? This paper argues that the European Union uses foreign aid as a public diplomacy tool to promote its own interests. To respond to these questions, the author used the qualitative methodology by means of explanatory research to narrow the broad assumptions related to the research topic. Secondary data from books, peer reviewed journals, and relevant government and OECD reports were applied to come out with the the findings. Data collected was analysed by applying a thematic approach due to the potential subjective nature of the qualitative data. The exploratory research approach relies on its appropriateness in analysing vast quantities of qualitative data by organising the data into specific themes that are recurrent in the data (Bearman, 2013). Exploratory research also helped the author to be creative in order to gain the most amount of insight on a subject as focused on theory building (Opoku, 2016).

\section{Essence of Diplomacy}

First, diplomats often pursue the interests of their countries (Zielińska, 2016). Foreign aid is considered a part of diplomacy. Helping others is one effective method that has been used for years to create good relations among nations. It is the fundamental aim of diplomats to negotiate a deal or agreement that prioritises the needs and values of their countries. Diplomacy does not entail only establishing a good relationship with other states. Even in the pursuit of connections or helping others, the interest of diplomats' countries comes first. This point can be better illustrated by examining the regulations 
of various states in regard to development aid. Nations often identify specific policies or values that dictate their provision of assistance. For instance, Canada stipulates that its offer of international support should be in line with the vital Canadian values. These include promoting global citizenship, equity, and environmental sustainability as well as eradicating poverty (OECD, 2008). Japanese development policies insist that efforts to support others must, in turn, yield some benefits to the country in terms of strengthening prelateship, promoting exchanges, and building the status of Japan in the international platform (Junichi, 2017).

Other Western countries and the EU in general also attach foreign aid to its significant values, such as democracy, respect for diversity, peace, good governance, the rule of law, human rights, and many others (Lucarelli et al., 2006). As evident, foreign aid is attached to the interests and values of the donor. Countries are led by governments. However, governments are run by specific individuals. These individuals enter into foreign relationships with other authorities to realise their own interests. The idea assumes that rational theory continues to apply to all bilateral agreements and alliances. The theory assumes that every individual is rational. This means that people arrive at their decisions after making logical considerations. The choices are shaped by the perceived outcome of a given action. It is natural that individuals, including diplomats, choose decisions that provide them with more benefits and limit disadvantages (Zielińska, 2016). Diplomats need to secure better deals for their countries to build a positive image and a good reputation.

\section{Political Interests}

Foreign aid, as evident, is used to achieve political interests. Foreign aid has been used to promote democracy, which is an ideology that is thoroughly championed by the European Union and its members. Instilling democracy is one of the long-term intentions of foreign aid to African countries. The donors believe that democratic institutions are better positioned to realise economic and political development (Roger, 2014). This is because democracy promotes public participation and involvement in decision-making on the issue of national importance. In other words, efforts are geared to taking the power of decision-making to the local or ground level. Furthermore, donors insist that the public needs to be educated and trained to be able to participate in the political and governance process to further improve the quality of democracy (Robinson, 2008). These factors explain why foreign aid has also been given to groups rebelling against governments that are perceived to be undemocratic.

Development aid is widely given to former colonies so as to maintain the political links (Keukeleire et al., 2014). They need to keep a positive image of themselves even after decolonisation. Aid is used to reinforce the 
superiority perception of EU members and other Western countries. It is also common that the economic, political, and social progress realised by a country is linked to its former colonial powers. A political entity can be accused of incompetency when its former colonies are left in devastating conditions. To avoid such criticism, former colonisers try to ensure that their territories are left in better conditions. This explains why former colonies receive a significant or relatively larger amount of development aid from their colonial masters.

Foreign aid is also used to support gender equality and improve the living conditions as well as status of women in developing countries (Robinson, 2008). Female discrimination is a common topic. Women are paid less in employment, and few of them are given senior managerial positions. Additionally, they are highly vulnerable to physical violence. Yet, women play an essential role in society by taking care of families. The discrimination and suffering of women are more prevalent in Africa and other developing countries. The rate of domestic violence, poverty, illiteracy, and many other negative indicators of poor living conditions are prevalent in Africa. The dominant culture and values of African societies are more inclined to promote the superiority of males to females in the community. The EU and other Western countries have gender equality as one of their major priorities. The donors have provided funds to support many women empowerment groups in Africa (Robinson, 2008).

They have funded various projects concerned with increasing awareness of the existence and need to respect special women's rights. Some of the aid is focused on instilling critical agricultural and entrepreneurial skills to help realise economic freedom. Reliance on male partners as a source of financial support for their needs and families is one of the reasons that donors cite for continued discrimination of women in developing countries. Donors continue to remind beneficiaries of the importance and numerous benefits of integrating women into the growth of the economy.

Moreover, donor countries provide aid to counter threats that they face in the international arena. Donors, as mentioned earlier, compete to have more influence in African countries. Assistance is, thus, given as a tool for achieving a competitive edge over other countries attempting to have an influence on the beneficiaries. Donors increase aid to African countries when they feel that their control or power in such states is threatened. The rivalry was witnessed in the period of the Cold War. The Soviet Union increased aid to countries that were seen as more likely to be influenced by capitalism. The United States also increased support to countries that were seen to be moving towards communism (Olsen, 2007).

During the Cold War, threats of withdrawing aid were also used to force alliances between countries. Withdrawing assistance was used as a 
punishment for states that failed to embrace the donors' values and ideologies. When the Cold War ended, the US significantly cut down on development aid to African countries. The threat of communism for US capitalism came to a halt with the fall of the Soviet Union. Since the danger was not felt anymore, the US no longer saw the need to spend much on foreign aid (Keukeleire et al., 2014). In this way, development aid is used as a tool to defend the influence and status of the donor countries.

Development aid is used by the US and other Western countries to promote global security. Poor economic and living conditions increase crime among youth. Moreover, terrorists can easily recruit youth in a country with high levels of unemployment. The effect is more expounded on the youth who are the majority in most African countries. Security data indicate that criminal gangs, gun violence, and terrorist activities are more prevalent in poor neighbourhoods (Olsen, 2007). One of the major goals of the US and EU is to reinforce global security. The security of beneficiary countries is of vital consideration to donors.

\section{Economic Interests}

Foreign aid is used to protect vital natural resources in Africa and developing countries, which are also in high demand by Western countries (Riordan, 2005). For instance, Africa has the world's largest reservoirs of oil and natural gas. Furthermore, Ghana and Ivory Coast produce close to twothirds of the world's cocoa. Africa exports a relatively large amount of other agricultural products to donor countries. Developed nations, due to their industrialised status, are heavily reliant on oil and natural gas for running their industries. The production crisis experienced in the United States and other developed countries during the oil embargo enforced by OPEC countries is a clear demonstration of how dependent Western countries are on natural resources. As a result, it is in the interest of donors to ensure that they will continue to access these resources in the long run. For this reason, the developed countries insist that these resources be exploited in a reasonable and sustainable manner.

A large percentage of processing activities as well as value addition on agricultural products from Africa mainly take place in developed countries because of their advanced know-how. For instance, despite Ghana and the Ivory Coast producing the most significant volume of cocoa beans, major companies processing the raw material are from Western countries. It is in the best interest of Western countries to promote sustainable agricultural practice regarding the mentioned products so that they continue earning more revenues from their value-addition services. Also, consider that agricultural produce from Africa and other developing countries is sold cheaply in developed nations. Furthermore, Lake Victoria in Kenya is the largest inland freshwater 
body in the world as well as the source of the great River Nile. Using such vital resources irresponsibly may have significant negatives effects on other countries of the world.

For instance, global warming and climate change may limit the ability of Africa to produce vital raw materials for developed countries. Donors have increasingly supported projects to exploit renewable energy sources like solar power in African countries. In this way, foreign aid is used to influence African nations to embrace sustainable exploitation of resources that are also vital for the prosperity of donor countries (Lucarelli et al., 2006). Foreign aid is used to make beneficiary countries more open to investment from donor countries which always have several multinational companies. These firms need to be accommodated in developing countries (Jørgen, Niels \& Johannesen 2020), Emerging states provide a market for the goods produced in donor nations. Competition in donor countries may influence multinationals to exploit more opportunities in foreign markets. Developing countries, over recent years, have witnessed a significant increase in the size of their middle class (Karl, 2018).

This means that more people will be able to afford goods and services sold at higher prices. More technological products and other services from developed countries will be bought by Africans in the future. Africa has underexploited its resources due to inadequate funds, technology, and poor policies. Multinationals move to developing countries to take advantage of underexploited opportunities. For this reason, aid is offered to states that provide a free market (Crawford et al., 2019). Countries that discourage a free globalised market are considered unfit to receive foreign support. Thus, nations that embrace policies that are conducive to foreign direct investment are better positioned to benefit more. An open or free economy encourages donor countries to set up their industries across developing nations. Donors may, at some time, negotiate for better treatment of their foreign companies and lower restrictions on their imports. In this regard, foreign aid is issued to indirectly allow international companies access to the global market. Aid has also been used to campaign for privatisation. Donors consider privatisation as an effective way of opening an economy.

They emphasise the need for collaboration between private and public entities. Donors are against the establishment of state monopolies. They want the control of resources to be distributed among the people. Privatisation is a vital element of capitalism (Nasra, 2011). A country that campaigns for privatisation is conducive for foreign investments. The benefits realised by beneficiary countries trickle down to the developed or donor states. Development aid is designed to achieve economic progress in receiver countries. However, donors also benefit from economic growth realised by emerging nations (Dalgaard et al., 2017). There are several points of a contract 
through which financial gains in African countries trickle down to European nations. Ideally, African countries import goods from the developed world. African states with advanced economies receive highly valued imports from industrialised countries.

The phenomenon can be easily explained by the market forces of demand and supply. A prosperous African nation increases the demand for goods from industrialised countries. Multinational companies can sell their products and services at a premium price when the economic conditions in the beneficiary country are favourable. Increased expertise in developing countries allows donor states to access cheap skilled labour. Solving the health and other social challenges faced by Africa helps release more funds to be used in development projects and purchasing products from Western countries. Development aid may be costly to donors in the short term. However, in the long run, it has numerous positive impacts trickling down (Nasra, 2011).

\section{Restrictions on Development Aid}

Foreign aid is denied to countries with policies or values opposing to those of the donor states. Any nation that is perceived to be unfriendly is not considered as being entitled to foreign aid. For instance, parties that embraced communist ideologies are not likely to receive external support. The assistance is given to countries that choose to have a free economy. It cannot be given to nations that significantly disagree with the interests of donor countries. In Africa, the United States denied Angola and Libya foreign aid based on accusations of supporting terrorism and violating human rights (Riordan, 2005). In other words, donors give assistance to the developing countries whereby they find interests. The criteria used to judge the friendliness of a nation are also unclear. The judgment is based on subjective factors that are specific to the historical relationship between the donor and beneficiary countries. Foreign aid is majorly portrayed as help by the donor states, and, as such, it should be given to those that are in need. However, the mentioned countries were denied foreign aid, yet they were in need. It is evident that external support is conditioned on the promise that the beneficiary countries will embrace the values and ideologies of their donors.

It is worth noting that development aid is not only given directly by individual countries. Some global organisations like the World Bank and the International Monetary Funds (IMF) provide significant development aid to African countries (Edmore, 2019). The resources of these organisations are contributed by member nations. The amounts of contribution among members vary depending on the level of a country's development. In most cases, donor countries like the US and UK contribute a relatively more immense proportion of funds and efforts to these organisations compared to African nations. Due 
to their large size of the contribution, these significant donors have a substantial influence on the decisions of the international organisations in regard to who, when, how, and where aid should be sent (Melissen, 2005). The donor countries use their impact to reward or punish African countries, depending on how they align or conflict with their ideologies and values.

\section{Case of Israel}

Israel's development aid to African countries between 1956 and 1973 can be used as a case example to illustrate how relief satisfies the political and strategic interests of the donors. Israel was not yet a prosperous nation as it is now. However, it had achieved immense success in the fields of education, health, agriculture, afforestation, and many others. Since the country had fewer resources, its soft power in diplomacy was based on its know-how. The institutions of Israel played a huge role in training Africans. Consequentially, the transfer of expertise involved deep interactions between Africans and Israelites, thus creating positive relations. The development aid was inspired by an inherent ethos of the Jewish people; in that, they have a moral responsibility to help others and make the world a better place.

When providing aid, Israel was also seeking political alliances. It was surrounded by hostile neighbours. Consider that many states continued to dispute the authentic existence of Israel. To counter this pressure and hostility, Israel needed political allies. It used its expert aid to establish good relationships with more than 30 African countries. Jerusalem was a significant area of dispute. Arab nations insisted that Jerusalem belonged to Palestine. On the other hand, Israel held that Jerusalem was part of its territories and recognised it as the capital city. The sub-Saharan countries that received aid from the Israelites went on to later establish their consulates with Israel in Jerusalem. This was an expression of their political support to the country in regard to recognising Jerusalem as part and capital of Israel. African countries also vehemently opposed anti-Israel opinions on the international platform.

Their voting patterns at the United States General Assembly (UNGA) were more in favour of Israel (Finey, 1983). The behaviours of African countries at that time were seen as a way of returning the favour to Israel. Other Western countries used foreign aid to influence the voting process of beneficiaries at the UNGA. The use of aid to create allies is not a new practice. To illustrate this point, it is essential to consider the historical background of development aid. Assistance in the begging, foreign aid was meant mainly for warring nations. In most cases, the survival of the warring nation was vital to the economic and political prosperity of the donor country. In other words, aid was originally given to protect the interests of donors in beneficiary countries (Keukeleire et al., 2014). The use of foreign support to create alliances is a common policy strategy for European countries. 


\section{Improving Image and Reputation}

All interactions between countries, whether in the form of foreign aid or not, have a significant impact on their images. These connections can evoke a positive or negative perception of the donor country. Foreign aid, however, tends to reinforce a positive image of the donor (Riordan, 2005). For example, the beneficiary countries become more interested in the donor states. They help initiate a positive emotional appeal. The beneficiary is then influenced to purchase products from the donor country. Foreign aid is, thus, used to establish good trade relationships as well as agreements between beneficiary and donor states. Giving help earns the donor country a good reputation. The beneficiaries are influenced to perceive the donor as a partner that genuinely cares about their welfare. In turn, they reciprocate the goodwill and help increase the volume of trade with the donor countries. They also send locals to receive training and education in donor nations. Furthermore, beneficiaries begin to support the donor states' values and ideologies. Technological advancement portrays the donor country as having advanced know-how. Thus, the recipient may be influenced to trust the quality of the services and industrial products from the donor nation.

\section{Protecting Donor Citizens and Their Properties}

Foreign aid is used to protect the citizens of donor countries and their properties (Melissen, 2005). Donors do not give assistance to countries that fail to safeguard foreign citizens and their valuables. The beneficiary is also required to ensure the safety of the investments of the citizens, including state embassies. In other words, the beneficiary country enters into an implied agreement to compensate for any damage caused to citizens of donor countries. The donor countries know that they have many of their citizens in beneficiary states working as experts or in serious businesses. Their intention is to ensure that the citizens living abroad are adequately protected. Living in a foreign land comes with unique risks.

For instance, the government can decide to nationalise all overseas properties. On August 4th, 1972, Idi Amin, the then Ugandan president ordered all Indians in the country to close their shops and leave (Madsen, 2019). The properties were later given to the Ugandans, and mostly those that were favoured by Amin. Foreign citizens have been accused of taking over the jobs and businesses of the locals. For instance, globalisation has been found to have more benefits to developed countries than developing ones. Developed nations have more resources and technology to exploit the opportunities presented by globalisation. In some cases, multinationals from developed countries are perceived to use the local resources of citizens in the emerging world (Crawford et al., 2019). Such an attitude among citizens of the host country can create a hostile environment for foreigners. Consider that anti- 
imperialist countries such as Libya during the reign of Gadhafi were against the capitalist investments from Western countries.

In 1979, the US withdrew foreign aid from Ethiopia when the state nationalised properties belonging to 21 American firms and citizens (Melissen, 2005). Ethiopia would later make a declaration to compensate for the properties, but the plan was not completely implemented. Additionally, foreign aid is conditioned on the basis that the beneficiary country honours the debts owed to the citizens and businesses of the donor nations. This stipulation of settling due debts is encapsulated in the foreign policy approach of the United States and European countries. Extending coverage to debt is a way in which donor countries attempt to guarantee the safety of their citizens and properties abroad.

\section{Aid and Influence in Internal Affairs}

The amount of foreign aid dictates the extent to which a donor country can influence the practices and values of the beneficiary countries. Poor nations receive assistance from many different donors. However, the proportion of aid given by donors varies significantly. Those who offer more have a more significant say in the domestic issues and other decisions of the beneficiary countries (Finey, 1983). They can influence the economic and social policies of the beneficiaries.

For example, these donor countries are given special audiences and a platform to contribute to important decisions. In this regard, donors compete on the amount of foreign aid provided, depending on the extent to which they want to be able to influence internal affairs. Historically, consider that the United States and Russia increased assistance to those African countries which supported capitalism and communism respectively.

Another illustration of how foreign aid is targeted at the increasing influence of donor countries is evident in choice of beneficiary countries. It is true that underdeveloped nations need foreign assistance the most. However, this is not entirely true. Even countries considered to be economically superior receive external support. They may also be given a relatively larger amount of aid. Countries like Kenya, Egypt, Nigeria, and Morocco, which are economic giants in the African continent, receive substantial foreign support from donors. These countries are most likely to be targeted because of their influence in the region. The countries have a significant impact on the economic, social, and political development of other states on the continent. By being more influential in the major states, donors can play a significant role in the affairs of the continent (Finey, 1983). To achieve this, donors can direct more aid to the targeted beneficiary country. 
X. Supportive charts and graphs TOP 10 ODA recipients, USD million, net disbursements in 2015

\begin{tabular}{|c|c|c|c|}
\hline 1 & Ethiopia & 3234 & $6 \%$ \\
\hline 2 & Democratic Republic of the Congo & 2599 & $5 \%$ \\
\hline 3 & Tanzania & 2580 & $5 \%$ \\
\hline 4 & Egypt & 2448 & $5 \%$ \\
\hline 5 & Kenya & 2474 & $5 \%$ \\
\hline 6 & Nigeria & 2432 & $5 \%$ \\
\hline 7 & Mozambique & 1815 & $4 \%$ \\
\hline 8 & Ghana & 1768 & $3 \%$ \\
\hline 9 & South Sudan & 1675 & $3 \%$ \\
\hline 10 & Uganda & 1628 & $3 \%$ \\
\hline 10 & Other recipients & 28343 & $56 \%$ \\
\hline & Total & 51036 & $100 \%$ \\
\hline
\end{tabular}

The table above demonstrates top 10 development recipient countries in Africa as of 2015. It indicates that the countries Ethiopia, DR of the Congo, Tanzania, Egypt, Kenya, Nigeria,

Mozambique, Ghana, South Sudan and Uganda shared 54\% of the ODA Aid in 2015.

Source: www.oecd.org

\section{TOP 10 ODA donors, USD million, net disbursements in 2015}

\begin{tabular}{|c|c|c|c|}
\hline 1 & United States & 9320 & $18 \%$ \\
\hline 2 & EU institutions & 6246 & $12 \%$ \\
\hline 3 & IDA & 5176 & $10 \%$ \\
\hline 4 & United Kingdom & 4203 & $8 \%$ \\
\hline 5 & Germany & 3036 & $6 \%$ \\
\hline 6 & United Arab Emirates & 2835 & $6 \%$ \\
\hline 7 & France & 2292 & $4 \%$ \\
\hline 8 & Global Fund & 2211 & $4 \%$ \\
\hline 9 & African Development Bank & 2182 & $4 \%$ \\
\hline 9 & Japan & 1765 & $3 \%$ \\
\hline 10 & Other recipients & 11770 & $23 \%$ \\
\hline & Total & 51036 & $100 \%$ \\
\hline
\end{tabular}

The table below indicates top 10 development aid donor countries as of 2015. It indicates that the donor countries United States, EU institutions, United Kingdom, Germany, United Arab Emirates, France, Global Fund, African Development Bank, Japan, shared $77 \%$ of the overall development aid in 2015.

Source: www.oecd.org 


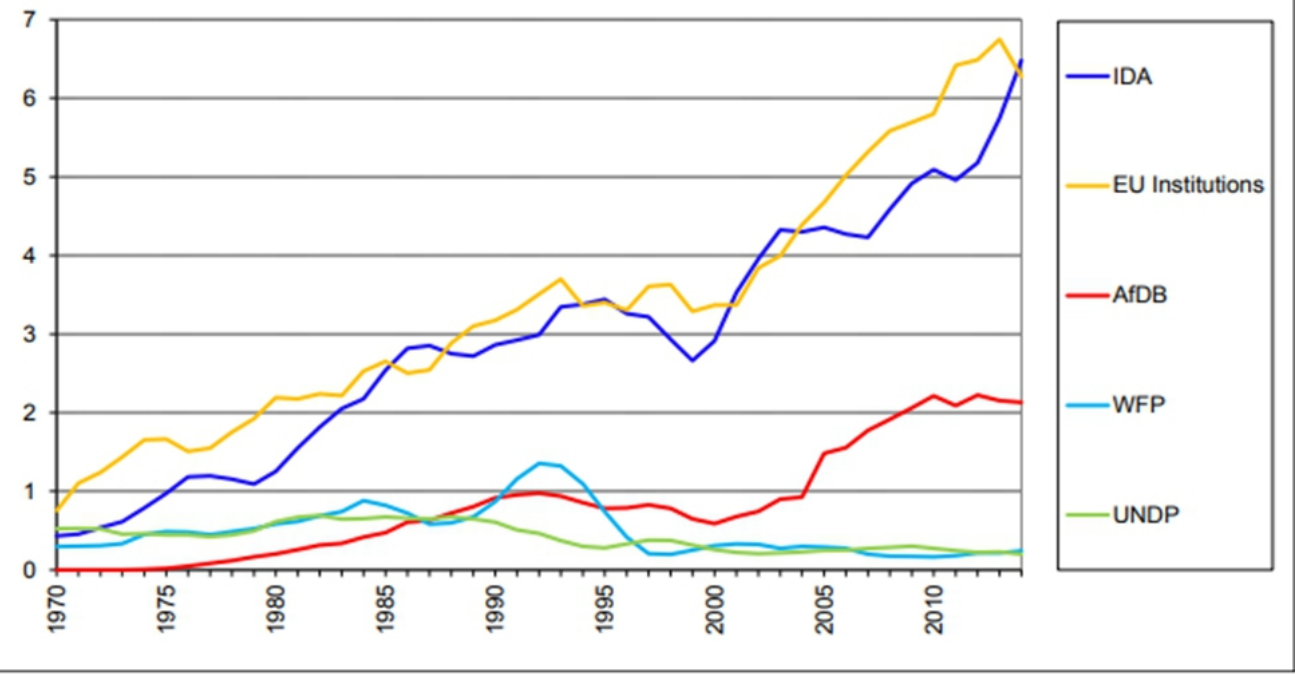

The graph above indicates the stakeholders of the development aid to Africa and shows the evolution of aid by multinational donors in USD Billions up to 2010.

Source: www.oecd.org

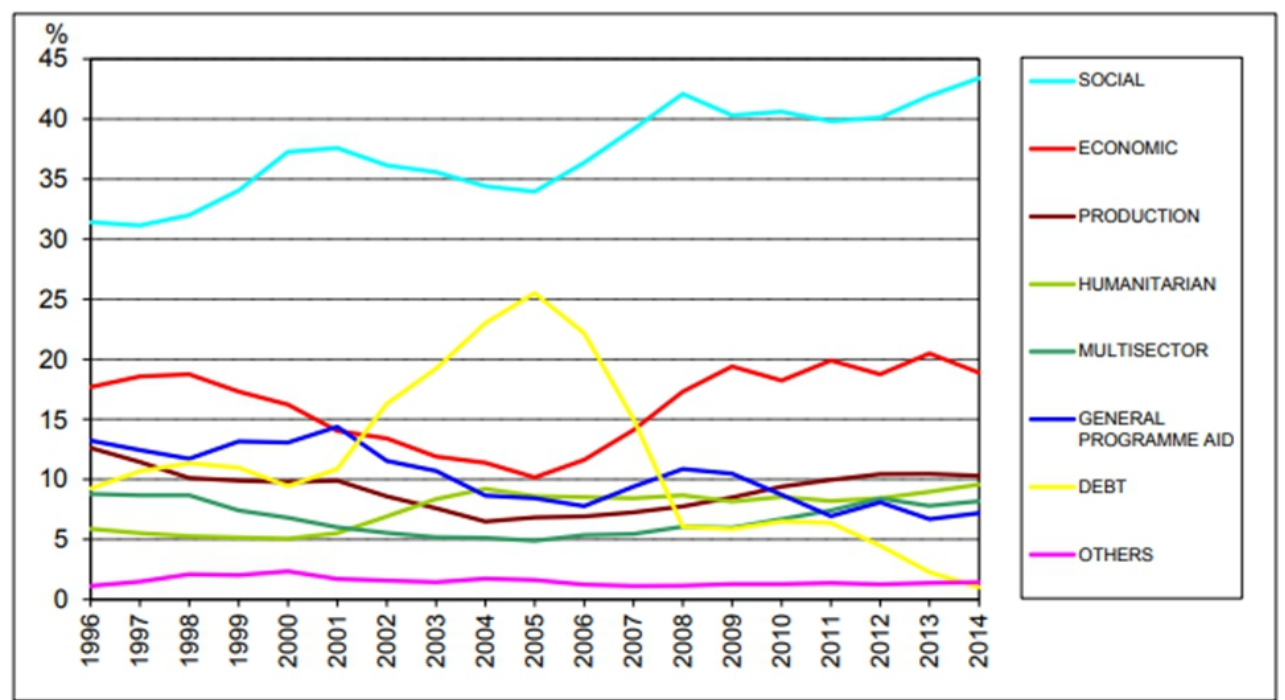

The graph above indicates the evolution of the development aid to Africa up to 2014. It also shows the development aid to Africa by sector in percentage.

Source: www.oecd.org 


\begin{tabular}{|c|c|c|c|c|c|c|}
\hline $\begin{array}{l}\text { Top } 10 \\
\text { multilateral } \\
\text { donors to Africa, } \\
\text { USD million, net } \\
\text { disbursements }\end{array}$ & & 2014 & 2015 & 2016 & $\begin{array}{l}\text { 3-year } \\
\text { average }\end{array}$ & $\begin{array}{r}\% \text { of all } \\
\text { multilaterals }\end{array}$ \\
\hline 1 & $\begin{array}{l}\text { International } \\
\text { Development Association }\end{array}$ & 6386 & 6246 & 5844 & 6159 & $31 \%$ \\
\hline 2 & EU Institutions & 6737 & 5176 & 6328 & 6080 & $30 \%$ \\
\hline 3 & Global Fund & 1957 & 2211 & 2622 & 2264 & $11 \%$ \\
\hline 4 & $\begin{array}{l}\text { African Development } \\
\text { Fund }\end{array}$ & 1904 & 2059 & 2029 & 1997 & $10 \%$ \\
\hline 5 & $\begin{array}{l}\text { Global Alliance for } \\
\text { Vaccines and } \\
\text { Immunization }\end{array}$ & 844 & 1016 & 755 & 871 & $4 \%$ \\
\hline 6 & UNICEF & 525 & 540 & 549 & 538 & $3 \%$ \\
\hline 7 & $\begin{array}{l}\text { Global Environment } \\
\text { Facility }\end{array}$ & 234 & 218 & 257 & 236 & $1 \%$ \\
\hline 8 & UNDP & 239 & 235 & 221 & 232 & $1 \%$ \\
\hline 9 & IFAD & 209 & 182 & 239 & 210 & $1 \%$ \\
\hline \multirow[t]{3}{*}{10} & $\begin{array}{l}\text { IMF (Concessional Trust } \\
\text { Funds) }\end{array}$ & 243 & 361 & 23 & 209 & $1 \%$ \\
\hline & Other multilaterals & 1394 & 1535 & 1185 & 1371 & $7 \%$ \\
\hline & Total multilaterals & 20673 & 19778 & 20052 & 20168 & $100 \%$ \\
\hline
\end{tabular}

These are the 10 top multilateral donors to Africa in terms of USD millions. It is available at http://www.oecd.org/dac/financing-sustainable-development

\begin{tabular}{|c|c|c|c|c|c|}
\hline $\begin{array}{l}\text { Top } 10 \text { ODA recipients in Africa } \\
\text { USD million, receipts from all donors, } \\
\text { net ODA receipts }\end{array}$ & 2014 & 2015 & 2016 & $\begin{array}{l}\text { 3-year } \\
\text { average }\end{array}$ & $\begin{array}{l}\% \text { of all } \\
\text { recipients }\end{array}$ \\
\hline 1 Ethiopia & 3584 & 3234 & 4074 & 3630 & $7 \%$ \\
\hline 2 Egypt & 3538 & 2499 & 2130 & 2722 & $5 \%$ \\
\hline 3 Tanzania & 2651 & 2582 & 2318 & 2517 & $5 \%$ \\
\hline 4 Nigeria & 2479 & 2432 & 2501 & 2470 & $5 \%$ \\
\hline 5 Kenya & 2661 & 2464 & 2189 & 2438 & $5 \%$ \\
\hline 6 Democratic Republic of the Congo & 2400 & 2599 & 2107 & 2369 & $5 \%$ \\
\hline 7 Morocco & 2240 & 1481 & 1992 & 1905 & $4 \%$ \\
\hline 8 Mozambique & 2106 & 1815 & 1531 & 1817 & $4 \%$ \\
\hline 9 South Sudan & 1964 & 1675 & 1590 & 1743 & $3 \%$ \\
\hline 10 Uganda & 1634 & 1628 & 1757 & 1673 & $3 \%$ \\
\hline Other recipients & 28827 & 28635 & 27764 & 28409 & $55 \%$ \\
\hline Total ODA recipients & 54083 & 51044 & 49954 & 51694 & $100 \%$ \\
\hline
\end{tabular}

These are the 10 top ODA recipients in Africa in terms of USD million and it is available at http://www.oecd.org/dac/financing-sustainable-development 


\begin{tabular}{|c|c|c|c|c|c|c|c|c|c|}
\hline \multirow{2}{*}{\multicolumn{2}{|c|}{$\begin{array}{l}\text { USD million, } 2015 \text { prices } \\
\text { and exchange rates, net } \\
\text { ODA receipts 2010-16 } \\
\text { Share }(\%)\end{array}$}} & 1970-79 & \multicolumn{2}{|c|}{$1980-891990-99$} & $\begin{array}{l}2000- \\
09\end{array}$ & \multirow[t]{2}{*}{$2010-16$} & 2014 & \multirow[t]{2}{*}{2015} & \multirow[t]{2}{*}{2016} \\
\hline & & \multicolumn{4}{|c|}{ Annual averages } & & Annual amounts & & \\
\hline Algeria & 0.3 & 532 & 341 & 371 & 294 & 148 & 139 & 87 & 157 \\
\hline Angola & 0.5 & 44 & 204 & 472 & 466 & 241 & 213 & 380 & 207 \\
\hline Benin & 1.1 & 149 & 235 & 324 & 424 & 535 & 531 & 430 & 492 \\
\hline Botswana & 0.2 & 161 & 239 & 140 & 142 & 99 & 94 & 66 & 89 \\
\hline Burkina Faso & 2.0 & 289 & 461 & 532 & 720 & 972 & 1010 & 997 & 1023 \\
\hline Burundi & 1.1 & 150 & 319 & 252 & 355 & 514 & 455 & 367 & 737 \\
\hline Cabo Verde & 0.4 & 35 & 144 & 154 & 154 & 200 & 200 & 153 & 112 \\
\hline Cameroon & 1.3 & 394 & 461 & 666 & 893 & 626 & 755 & 663 & 753 \\
\hline Central African Republic & 0.7 & 133 & 261 & 195 & 131 & 339 & 538 & 487 & 501 \\
\hline Chad & 1.0 & 220 & 279 & 302 & 344 & 473 & 348 & 607 & 625 \\
\hline Comoros & 0.1 & 60 & 91 & 52 & 34 & 65 & 65 & 66 & 55 \\
\hline Congo & 0.6 & 156 & 196 & 249 & 290 & 275 & 92 & 89 & 87 \\
\hline Côte d'Ivoire & 2.3 & 312 & 404 & 1047 & 593 & 1130 & 833 & 653 & 656 \\
\hline $\begin{array}{l}\text { Democratic Republic of } \\
\text { the Congo }\end{array}$ & 5.9 & 705 & 890 & 371 & 2015 & 2858 & 2175 & 2599 & 2125 \\
\hline Djibouti & 0.3 & 104 & 169 & 139 & 100 & 142 & 146 & 170 & 185 \\
\hline Egypt & 4.5 & 4771 & 3116 & 4110 & 1409 & 2170 & 3138 & 2499 & 2127 \\
\hline Equatorial Guinea & 0.0 & 9 & 48 & 52 & 28 & 18 & 0 & 7 & 7 \\
\hline Eritrea & 0.2 & 5 & 6 & 129 & 260 & 99 & 75 & 94 & 67 \\
\hline Ethiopia & 7.0 & 357 & 1006 & 1172 & 2180 & 3401 & 3270 & 3234 & 4124 \\
\hline Gabon & 0.2 & 127 & 150 & 129 & 41 & 74 & 95 & 99 & 41 \\
\hline Gambia & 0.2 & 46 & 140 & 85 & 80 & 106 & 90 & 108 & 93 \\
\hline Ghana & 3.0 & 291 & 566 & 782 & 1150 & 1453 & 1013 & 1769 & 1324 \\
\hline Guinea & 0.9 & 75 & 306 & 447 & 267 & 422 & 499 & 538 & 559 \\
\hline Guinea-Bissau & 0.2 & 56 & 151 & 155 & 107 & 111 & 97 & 95 & 198 \\
\hline Kenya & 4.9 & 512 & 1070 & 877 & 932 & 2360 & 2451 & 2464 & 2196 \\
\hline Lesotho & 0.4 & 102 & 210 & 140 & 94 & 193 & 100 & 83 & 113 \\
\hline Liberia & 1.6 & 86 & 194 & 146 & 385 & 795 & 681 & 1094 & 810 \\
\hline Libya & 0.4 & 29 & 38 & 6 & 19 & 190 & 189 & 157 & 182 \\
\hline Madagascar & 1.0 & 260 & 500 & 531 & 721 & 491 & 522 & 677 & 621 \\
\hline Malawi & 2.0 & 237 & 396 & 605 & 651 & 990 & 842 & 1049 & 1258 \\
\hline Mali & 2.3 & 325 & 661 & 554 & 715 & 1115 & 1088 & 1204 & 1210 \\
\hline Mauritania & 0.6 & 331 & 409 & 292 & 319 & 305 & 230 & 318 & 290 \\
\hline Mauritius & 0.2 & 75 & 94 & 53 & 45 & 101 & 36 & 78 & 42 \\
\hline Mayotte & 0.2 & 9 & 48 & 117 & 265 & 75 & - & - & - \\
\hline Morocco & 3.1 & 838 & 1369 & 1022 & 833 & 1511 & 1936 & 1481 & 1976 \\
\hline Mozambique & 3.8 & 116 & 788 & 1420 & 1681 & 1841 & 1899 & 1815 & 1532 \\
\hline Namibia & 0.5 & 0 & 20 & 212 & 194 & 220 & 217 & 142 & 169 \\
\hline Niger & 1.6 & 347 & 512 & 403 & 484 & 770 & 811 & 868 & 951 \\
\hline Nigeria & 4.5 & 301 & 135 & 282 & 2444 & 2162 & 2283 & 2432 & 2550 \\
\hline Rwanda & 2.1 & 232 & 384 & 547 & 604 & 1016 & 937 & 1085 & 1157 \\
\hline Saint Helena & 0.2 & 15 & 35 & 22 & 30 & 110 & 122 & 82 & 118 \\
\hline Sao Tome and Principe & 0.1 & 7 & 30 & 63 & 40 & 47 & 36 & 49 & 47 \\
\hline Senegal & 1.8 & 421 & 871 & 741 & 773 & 891 & 999 & 879 & 735 \\
\hline Seychelles & 0.0 & 47 & 42 & 26 & 21 & 21 & 11 & 7 & 6 \\
\hline Sierra Leone & 1.2 & 66 & 158 & 188 & 408 & 587 & 828 & 946 & 715 \\
\hline Somalia & 2.0 & 413 & 896 & 469 & 343 & 959 & 992 & 1253 & 1194 \\
\hline South Africa & 2.4 & - & - & 385 & 788 & 1165 & 1003 & 1420 & 1173 \\
\hline South Sudan & 2.3 & - & - & - & - & 1123 & 1818 & 1675 & 1607 \\
\hline Sudan & 2.6 & 691 & 1691 & 556 & 1397 & 1255 & 803 & 900 & 816 \\
\hline Swaziland & 0.2 & 67 & 70 & 59 & 39 & 102 & 81 & 93 & 147 \\
\hline
\end{tabular}




\begin{tabular}{|c|c|c|c|c|c|c|c|c|c|}
\hline Tanzania & 5.3 & 731 & 1462 & 1315 & 2006 & 2581 & 2419 & 2582 & 2331 \\
\hline Togo & 0.5 & 158 & 245 & 195 & 140 & 256 & 185 & 200 & 165 \\
\hline Tunisia & 1.4 & 637 & 466 & 292 & 354 & 670 & 792 & 475 & 625 \\
\hline Uganda & 3.2 & 131 & 437 & 908 & 1374 & 1576 & 1497 & 1628 & 1766 \\
\hline Zambia & 1.9 & 286 & 669 & 1023 & 1104 & 919 & 919 & 797 & 964 \\
\hline Zimbabwe & 1.5 & 16 & 485 & 551 & 361 & 740 & 697 & 788 & 667 \\
\hline $\begin{array}{l}\text { North of Sahara, } \\
\text { regional }\end{array}$ & 0.6 & 17 & 27 & 49 & 146 & 268 & 218 & 305 & 279 \\
\hline $\begin{array}{l}\text { South of Sahara, } \\
\text { regional }\end{array}$ & 5.2 & 539 & 747 & 752 & 1618 & 2529 & 3047 & 2435 & 2658 \\
\hline Africa, regional & 4.4 & 228 & 666 & 753 & 918 & 2116 & 2177 & 3325 & 2800 \\
\hline Africa total & 100 & 17450 & 26009 & 27881 & 34725 & 48522 & 48739 & 51044 & 50211 \\
\hline
\end{tabular}

This table shows the prices and exchange rates of net ODA receipts 2010-16 and it is available at http://www.oecd.org/dac/financing-sustainable-development

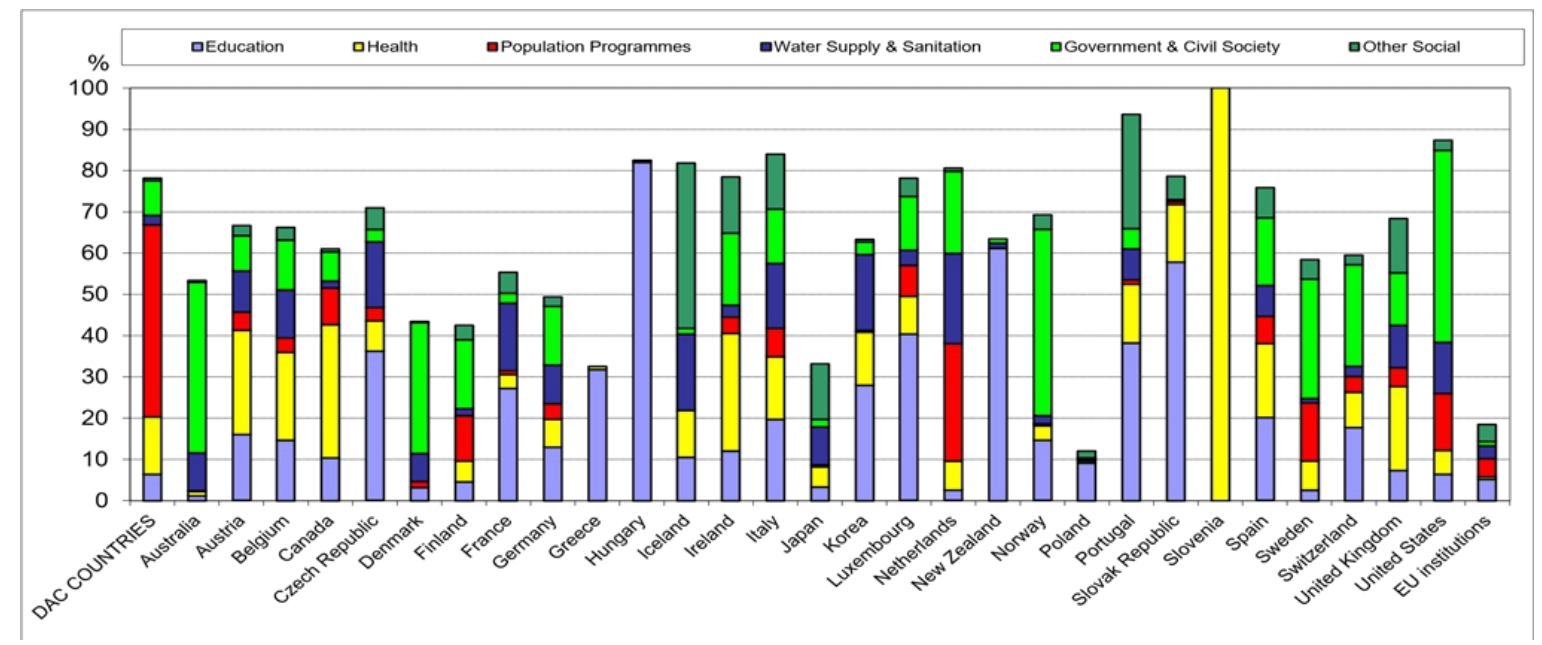

It analyses the social sector ODA to Africa by donor

as a percentage of total sector-allocable commitments for each donor in 2016 it is Available at http://www.oecd.org/dac/financing-sustainable-development 


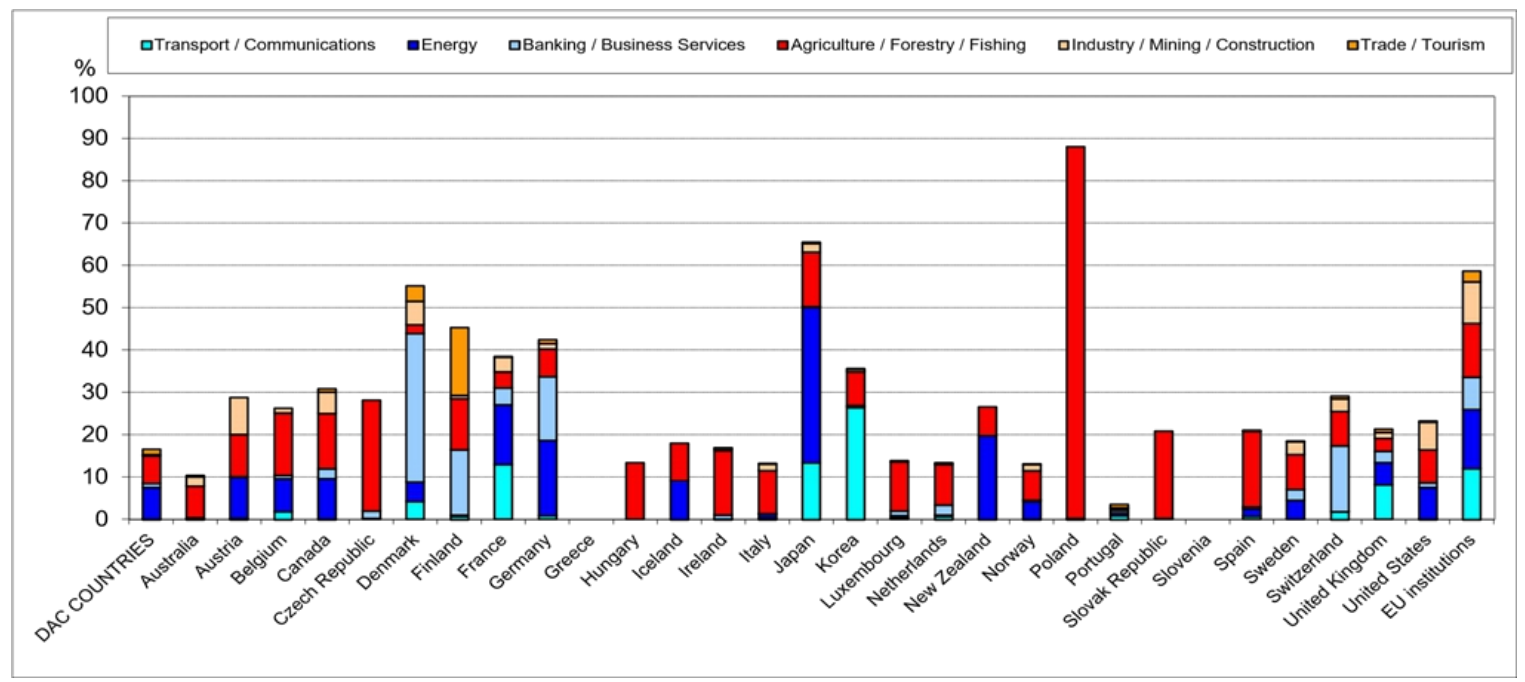

It analyses the economic and production sector of the ODA to Africa by donor as a percentage of total sector-allocable commitments for each donor in 2016 it available at http://www.oecd.org/dac/financing-sustainable-development

\section{Recommendations}

African countries should embrace the ideology of self-reliance. Several states that have done so have successfully achieved economic prosperity. Africa should reduce its dependence on development aid. The continent is endowed with enough resources. African countries are among the world's largest oil and natural gas producers. Africa is also rich in deposits of valuable minerals, such as diamond, gold, copper, and many others. Moreover, the continent is home to unique wildlife, which can be used to attract tourists and consequentially earn African countries vast amounts of money in terms of foreign exchange. Ivory Coast and Ghana produce 60 per cent of the world's coffee.

The tropical climates in Africa are conducive for agriculture. The region also has the highest population of young people; thus, labour is readily available at low costs. Africa only needs to devise ways in which these resources can be utilised effectively and efficiently. African countries should challenge themselves in value addition and advancing know-how. Continued reliance on development aid causes an inferiority perception and approach among African countries (Olsen, 2007). The lack of confidence makes African nations not exploit their full potential. The continuous flow and increase in development aid are also not guaranteed. Donor countries may limit the amount of assistance to African nations. For instance, consider the current Trump administration in the US. It has already displayed a negative attitude towards development aid. Trump has insisted that his government will put America first (Nasra, 2011). The announcement could have a more significant impact, given that the US is the world's largest donor. Development aid is not 
an obligation to EU countries. Instead, it is a moral act to assist another. African countries cannot force the EU and the US to provide them with aid when they refuse to do so.

African countries should establish a free trade and employment system. This will open up all African countries for investment. The European Union, for instance, has been a dominant power economically in the international stage because it has a single and free market. The percentage of trade between African countries is the lowest in the world, standing at about $12 \%$. There is a huge difference when compared to the figure for the EU, which is approximately 60\% (Nasra, 2011). The EU encourages the free movement of goods and people between the boundaries of member states. However, this is not true in the case of Africa. Tariffs and other statutory obligations on international trade are heavily implemented even among immediate neighbours. African countries have not yet opened to investments from their selves.

The restricted access to other markets derails economic growth in Africa. Opportunities are left underutilised. Also, ideas and information spread at a lower rate. The volume of sales for a product or service becomes limited to a specific geographic population. As such, exporting goods to other African countries becomes expensive. A free market will increase employment and poverty. It will also promote the transfer of ideas and skills.

The donor countries need to minimise conditions and restrictions when providing development aid to African states. People will not consider funding as help when it comes along with numerous conditions. In this regard, donor countries may fail to build a positive image of their governments in the beneficiary nations. Creating a positive image of the donor country is one of the major objectives of diplomatic relations.

Note that the restrictions also deny aid to African countries that are in dire need. When assistance is intentionally meant to promote the welfare and development of emerging countries, the selection criteria should be based on the extent of need (Keukeleire \& Delreux, 2014).

Again, donor countries should consider the cultural and contextual factors of beneficiary states. The conditions attached to foreign aid should not disrespect the values and cultures of African countries. The terms of foreign aid may not be consistent with the prevailing circumstances in the receiving country. Funding is increasingly being used to influence the internal affairs and decisions of beneficiary countries. In this regard, foreign aid can also be used as an intrusive tool. This application of foreign aid is against the principle of state sovereignty. National constitutions and international articles recognise that governments as sovereign in their territories. They have the right to make their own decisions without interference from third parties. 
By attaching conditions to foreign aid, donors interfere with the independence of decision-making in beneficiary countries (Olsen, 2007). Emerging states are forced to embrace their donors' ideologies and policies because they are in dire need of aid. The donor countries also need to increase the proportion of aid given to African states. Currently, the proportion set aside for development aid in Africa by Western countries is relatively low. For instance, consider that the US spends only about $1 \%$ of its GDP on development aid, yet it is the largest donor (Olsen, 2007). The amount of assistance cannot be compared to the billions of revenues that donor countries earn by trading with Africa. For this reason, it is expected that donor countries can quickly increase the aid to Africa with little inconvenience. The assistance that has been given to African countries is not enough.

\section{Conclusion}

From the discussion above, it is evident that development aid is used as a foreign policy tool to satisfy the interests of donor countries. It cannot be denied that assistance is meant to improve African countries economically, politically, and socially. However, over recent years, aid has evolved to become a vital instrument in promoting the values and interests of donors. Development aid cannot only be providing help to fewer unfortunate countries. Instead, it is used to realise some political and strategic goals. The political and strategic application of development aid is evidenced by the selection of beneficiary countries, attached conditions, fundamental diplomacy rules, and many other factors.

European and other developed countries will continue to give development aid to African nations. It is evident that African countries cannot address the challenges they currently face on their own. Given the tremendous economic potential of Africa, European nations would love to maintain positive relations. Development aid seems like a highly effective way to establish the required relationship. For this reason, the priority should be ensuring that development aid is appropriately used. It would be unfair to criticise European and Western countries for pursuing their interests through issuing development aid. The given assistance has been able to have positive impacts on African countries, even though to a limited extent.

Again, it would be unreasonable to require donor countries to put the interests of beneficiaries first and ignore their own foreign policy objectives. For these reasons, there should be a middle ground approach that balances the benefits of both donor and beneficiary countries (Nasra, 2011). The limited success of development support in African countries can be attributed to poor implementation of the aid programmes. Development aid is not always used properly by the receivers. Also, this may not be the fault of donors. African countries are challenged by high levels of corruption. For this reason, a 
significant amount of funds provided as development aid is diverted to the pockets of individuals. Again, inexperience and low competency levels among experts in African countries are another cause of poor results of development aid (Nasra, 2011).

Further studies should be conducted to examine the use of foreign aid by donors to achieve their own interests. The paper has provided a detailed analysis of the topic. However, there is still more to be discussed in regard to the use of foreign aid as a diplomacy tool. Future studies need to investigate how development aid can be used more efficiently while also prioritising the interests of beneficiaries. The paper has identified a problem and the manner in which development aid is used by donor countries. However, identifying a problem alone is not effective. There is a need for more research to unearth solutions to the identified problem.

\section{References:}

1. Aliza B. (2009). The Rise and Fall of Israel's Bilateral Aid Budget 1958-2008

2. Anup S. (2014). Foreign Aid for Development Assistance, $<$ https://www.globalissues.org/article/35/foreign-aid-developmentassistance $>$

3. Arakaza D. (2020). Impact of the Pan African Parliament in Promoting Gender balance

4. Crawford G. \& Kacarska, S. (2019). Aid Sanctions and Political Conditionality: Continuity and Change. Journal of International Relations and Development, 22(1), 184-214.

5. Creswell, J. W. (2013). Qualitative Inquiry and Research Design: Choosing Among Five Approaches. Los Angeles: Sage.

6. DAC \& Development Co-operation Directorate. (2007). Development Aid at a Glance...: Statistics by Region. OECD

7. Dalgaard J. Henrik H. (2017) The Return to Foreign Aid, Journal of Development Studies, Volume 53, 2017 - Issue 7

8. Edmore M. (2019). Foreign aid and poverty reduction: A review of international literature, Department of Economics, University of South Africa, Pretoria, South Africa

9. Finney L. D. (1983). Development Assistance--A Tool of Foreign Policy. Case W. Res. J. Int'1 L., 15, 213.

10. Jørgen A. Niels J. \& Johannesen B. (2020), Elite Capture of Foreign Aid Evidence from Offshore, $<$ http://articles.worldbank.org/curated/en/493201582052636710/pdf/ Elite-Capture-of-Foreign-Aid-Evidence-from-Offshore-BankAccounts > 
11. Junichi Y. (2017). Essays on Development Economics and Japanese Economic History, <https://pdfs.semanticscholar.org/54ab/502a104992f7cdcec86a3d7df 366b9f10bb5.pdf>

12. Karl M. (2018). As a system, foreign aid is a fraud and does nothing for inequality,

https://www.theguardian.com/commentisfree/2018/sep/02/as-asystem-foreign-aid-is-a-fraud-and-does-nothing-for-inequality >

13. Keukeleire S. \& Delreux T. (2014). The Foreign Policy of the European Union. Macmillan International Higher Education.

14. Kumiko H. (2013). Danger of "Specific Territory" on Senkaku (Daiaoyu) and Takeshima (Dokuto) considering from the European Union, World (Sekai), Iwanami Publisher

15. Lucarelli S. \& Manners I. (2006). Values and Principles in European Union Foreign Policy. Routledge.

16. Madsen P. (2019). When Idi Amin expelled 50,000 'Asians' from Uganda? Adam Smith Institute

17. Melissen J. (2005). The New Public Diplomacy (pp. 292-31). Basingstoke: Palgrave Macmillan.

18. Nasra S. (2011). Governance in EU Foreign Policy: Exploring Small State Influence. Journal of European Public Policy, 18(2), 164-180.

19. OECD. (2008). Annual report https://www.oecd.org/newsroom/40556222.pdf >

20. Olsen G. R. (2007). Between Development Policy and Foreign Policy Ambitions: The European Union Strategy for Africa.

21. Opoku, A.,Ahmed, V. \& Akotia, J. (2016). Choosing Appropriate Methodology and Method. In V.

22. Riordan S. (2005). Dialogue-Based Public Diplomacy: A New Foreign Policy Paradigm? In the New Public Diplomacy (pp. 180-195). Palgrave Macmillan, London.

23. Robinson J. (2008). Foreign Aid-a Global Foreign Policy Tool for Germany. GRIN Verlag.

24. Roger C. (2014). Does Foreign Aid Really Work? $<$ https://devpolicy.org/2014-Australasian-Aid-and-International-

Development-Policy-Workshop/Roger-Riddell-Background-

Paper.pdf or at Oxford Policy Management, Oxford UK http://www.opml.co.uk/ >

25. Zielińska K. (2016). Development Aid as a Part of Public Diplomacy in the Pursuit of Foreign Policy Aims: Theoretical and Practical Considerations. 